\title{
STABILITY OF CLOSE-CELL Al FOAMS DEPENDING ON THE USAGE OF DIFFERENT FOAMING AGENTS
}

\author{
STABILNOST ALUMINIJEVIH PEN Z ZAPRTO POROZNOSTJO \\ GLEDE NA UPORABO RAZLIČNIH PENILNIH SREDSTEV
}

\author{
Irena Paulin \\ Institute of Metals and Technology, Lepi pot 11, 1000 Ljubljana, Slovenia \\ irena.paulin@imt.si \\ Prejem rokopisa - received: 2015-10-21; sprejem za objavo - accepted for publication: 2015-10-28
}

doi:10.17222/mit.2015.322

\begin{abstract}
Close-cell Al foams produced by the powder-metallurgy (PM) route can be made with different foaming agents, regarding the type of liberated gas. Most commonly, $\mathrm{H}_{2}$ gas is used as the liberation agent, but there is a huge improvement made with $\mathrm{CO}_{2}$ gas liberating agents, such as calcite and dolomite. In order to determine the benefits and/or disadvantages of foaming agents, studies of the foam pores' stability, depending on the type of liberated gas, were performed.

The stability of Al foams was studied by different analytical techniques, i.e., AES, expandometer, heating microscopy and SEM/EDS. AlSi12 aluminium powder as the matrix material and $\mathrm{TiH}_{2}$ and $\mathrm{CaCO}_{3}$ as the foaming agents liberating different gases - one based on $\mathrm{H}_{2}$ and another on $\mathrm{CO}_{2}$ - were used. Based on the obtained results, the mechanism of foam stability was studied and a comparison of the two foaming agents was made and evaluated.

Keywords: $\mathrm{Al}$ foams, $\mathrm{CaCO}_{3}$, $\mathrm{TiH}_{2}$, stability of pores, oxide layers
\end{abstract}

Aluminijeve pene z zaprto poroznostjo, narejene po postopku metalurgije prahov, se lahko pripravi z različnimi penilnimi sredstvi glede na plin, ki se pri penjenju sprošča. Najbolj pogosto je uporabljeno penilno sredstvo na osnovi $\mathrm{H}_{2}$ plina, vendar se v zadnjem času veliko uporabljajo tudi penila na osnovi $\mathrm{CO}_{2}$, kot sta kalcit in dolomit. Da bi ugotovili prednosti in slabosti različnih penilnih sredstev, so bile narejene študije stabilnosti por glede na tip izhajajočega plina.

Stabilnost aluminijevih pen je bila raziskovana $\mathrm{z}$ različnimi analitskimi tehnikami - z AES, ekspandometrom, segrevalnim mikroskopom in SEM/EDS analizo. Za raziskavo smo uporabili aluminijev prah $\mathrm{AlSi}_{2} 2$ in $\mathrm{TiH}_{2}$ ter $\mathrm{CaCO}_{3} \mathrm{kot}_{\text {penilni sredstvi z }}$ različnima tipoma sproščenega plina - en na osnovi $\mathrm{H}_{2}$ in drugi na osnovi $\mathrm{CO}_{2}$. Glede na rezultate raziskave smo opisali mehanizem za stabilizacijo aluminijevih pen in primerjali ter ocenili obe penilni sredstvi.

Ključne besede: $\mathrm{Al}$ pene, $\mathrm{CaCO}_{3}, \mathrm{TiH}_{2}$, stabilnost por, oksidne plasti

\section{INTRODUCTION}

Al foams as a promising class of materials with great chances for applicative use ${ }^{1-3}$ due to their mechanical, chemical and physical properties were analyzed from different viewpoints. Most studies were performed on the synthesis, characterization and mechanical testing of foams, but few investigated the stability of foams by adding ceramic particles into the matrix and no analysis was made to explain the stability of the interior of the pores and the properties of the material depending on this stability.

The PM production process starts with mixing metal powders - elementary-metal powders, or alloyed powders or metal powder blends - and a foaming agent, after which the mixture is compacted to yield a dense, semi-finished product. ${ }^{4,5}$ The method depends on the preparation of the precursors ${ }^{6}$, which in principle can be made by any technique that ensures the embedding of the foaming agent into the metal matrix without any observable residual open porosity. In general, precursors consist of a compacted metallic powder and a foaming agent that are sintered at a pre-determined temperature. Due to the high temperature of the thermal treatment, the foaming agent decomposes into a solid component that is incorporated into the matrix material, and a gas component that causes foaming of the matrix material. ${ }^{7}$

The metal matrix is a semi-solid, thus the gas liberated from the agent is forming pores that give a specific shape and mechanical properties to the foams. The obtained foam must be rapidly and properly cooled down to retain the bloated structure. Pore formation depends on the amount and the type of the liberated gas, the time and temperature of the thermal treatment and the cooling process. All those parameters influence the stability of the pores and thus the stability of the material properties. The quantitative expansion and collapsing behaviors of the samples were characterized with a mechanical expandometer and heating microscopy.

This investigation is focused on the closed-cell Al foam produced by the powder metallurgy (PM) process using different gas-liberating foaming agents, such as $\mathrm{TiH}_{2}$ and $\mathrm{CaCO}_{3}$. The aim of the study was to investigate the mechanism of the stability of the $\mathrm{Al}$ foams to understand the process of pore formation, the possibility of predicting the foam properties and for the optimal selection of the foaming agent, depending on the expected properties. 


\section{EXPERIMENTAL PROCEDURES}

In the present study of Al-foam stability, the interior surfaces of the pores were carefully studied. AlSi12 aluminium powder, $\mathrm{TiH}_{2}$ and $\mathrm{CaCO}_{3}$ as the foaming agents liberating different gases - one based on $\mathrm{H}_{2}$ and the other on $\mathrm{CO}_{2}$ - were used. The decomposition of both foaming agents could be described by the two chemical reactions given below, and the volume of liberated gas was calculated from the ideal gas law:

$$
p V=n R T
$$

where $p$ is the pressure, $V$ is the volume of gas, $n$ is the amount of substance $(n=m / M$, where $m$ is the mass and $M$ is the molar mass), $R$ is the gas constant and $T$ is the temperature.

The decomposition of:

$$
\mathrm{TiH}_{2}: \mathrm{TiH}_{2}(\mathrm{~s}) \rightarrow \mathrm{Ti}(\mathrm{s})+\mathrm{H}_{2}(\mathrm{~g})
$$

$1 \mathrm{~g}$ of $\mathrm{TiH}_{2}$ liberates at $T=923 \mathrm{~K}\left(650^{\circ} \mathrm{C}\right)$ a gas volume of $V=1.51 \mathrm{~L}$

$$
\mathrm{CaCO}_{3}: \mathrm{CaCO}_{3}(\mathrm{~s}) \rightarrow \mathrm{CaO}(\mathrm{s})+\mathrm{CO}_{2}(\mathrm{~g})
$$

$1 \mathrm{~g}$ of $\mathrm{CaCO}_{3}$ liberates at $T=923 \mathrm{~K}\left(650^{\circ} \mathrm{C}\right)$ a gas volume of $V=0.76 \mathrm{~L}$

The calculation of the gas liberation at standard temperature and pressure shows that the volume of liberated gas is relatively high, but in the real foaming process, where the pressure of gas in the material is higher, the volume of gas is smaller. On the other hand, some of the liberated gas escapes out of the material when the pressure in the formed bubbles is too high. ${ }^{8,9}$ The process of pore formation can be explained by the theory of soap bubbles.

A calculation of the amount of liberated gas shows that the largest amount of gas liberated under the same conditions is obtained with the $\mathrm{TiH}_{2}$ decomposition, while the amount of liberated gas with the decomposition of $\mathrm{CaCO}_{3}$ is just a half of that. A calculation of the volumes of liberated gas gives how much foaming agent is needed for similar results of foaming.

All the samples were prepared by the same procedure, i.e., mixing the AlSi12 powder with mass fractions $1 \% \mathrm{TiH}_{2}$ and $3 \% \mathrm{CaCO}_{3}$, respectively, cold compaction at $1200 \mathrm{MPa}{ }^{6}$ into semi-products, called precursors, and foaming at a temperature that is specific for each foaming agent. ${ }^{10}$ After preparing the foams, some in a lab furnace and some in the expandometer, specimens were analyzed with different techniques: SEM/EDS (SEM JEOL 6500F with Oxford INCA EDX analyzer) was used for micro-chemical analyses of the inclusions in the foam thin walls, while the surface of the interior of the pores and the exterior of the foams were investigated by AES (Microlab $310 \mathrm{~F}$ VG-Scientific). AES depth profiles were performed by ion etching with a velocity of $0.125 \mathrm{~nm} / \mathrm{min}$. The AES surface analyses were also performed for the initial powder particles to confirm the presence of an oxide layer on the surface.
The mechanism of foam stability was explained by the investigation with heating microscopy and the expandometer. Both methods were used to determine the time and the temperature of foaming the material. In heating microscopy, small samples of precursor material with different foaming agents were put into the furnace within the microscope and heated up to $800{ }^{\circ} \mathrm{C}$ with a heating rate of $7{ }^{\circ} \mathrm{C} / \mathrm{min}$. Precursors were inserted at room temperature into the microscope and heated up until the foaming process did not stop and foams started to collapse. During the heating, changes to the shape and the size of the investigated material were observed. This method enabled us to determine the temperature of the foaming process start and the temperature of the foam collapse.

The mechanical expandometer was used to measure the expansion of the foamable precursors inside a cylindrical mould as a function of time and temperature. ${ }^{11}$ The temperature of the expandometer furnace was held constant at $750{ }^{\circ} \mathrm{C}$ for the $\mathrm{TiH}_{2}$ foaming agent and at 800 ${ }^{\circ} \mathrm{C}$ for the $\mathrm{CaCO}_{3}$ foaming agent.

\section{RESULTS AND DISCUSSION}

The foaming process was studied by observing precursors in the heating microscope during heating. Samples began to change their shape and volume at a certain temperature, depending on the type of foaming agent. The results obtained with the heating microscope enabled us to determine the approximate time and temperature of the beginning of the process. Changes of the foam expansion (precursor was made with AlSi12 + $\mathrm{TiH}_{2}$ ) are represented in Figure 1.

The heating microscope also enabled us to observe the collapsing of the foams after extended foaming times at individual temperatures. This resulted in gas escaping from the bubbles that were formed inside the matrix material. At a certain temperature, the matrix material became viscous, which prevented the escape of gas from the material. Higher temperatures caused a drop in the material viscosity, and due to pressure in the gas bubbles the gas escaped and the foam collapsed. That was the reason that the foams had to be cooled down fast after the desired expansion of material was achieved. Cooling could be achieved either by immersing the foamed product into water or with cold compressed air. In our case cooling in water was applied.

Foams prepared with different foaming agents were cut into smaller pieces and samples for the investigation with SEM/EDS were prepared, using a standard metallographic procedure with grinding and polishing. Figures 2 and 3 show SE (secondary electron) and BE (backscattered) images of the polished foamed material, where residuals of solid particles of foaming agents captured in the walls of the foams after the gas liberation are visible.

$\mathrm{In}^{12,13}$ the authors confirmed that those ceramic particles helped to stabilize the $\mathrm{Al}$ foams. In analyses of 

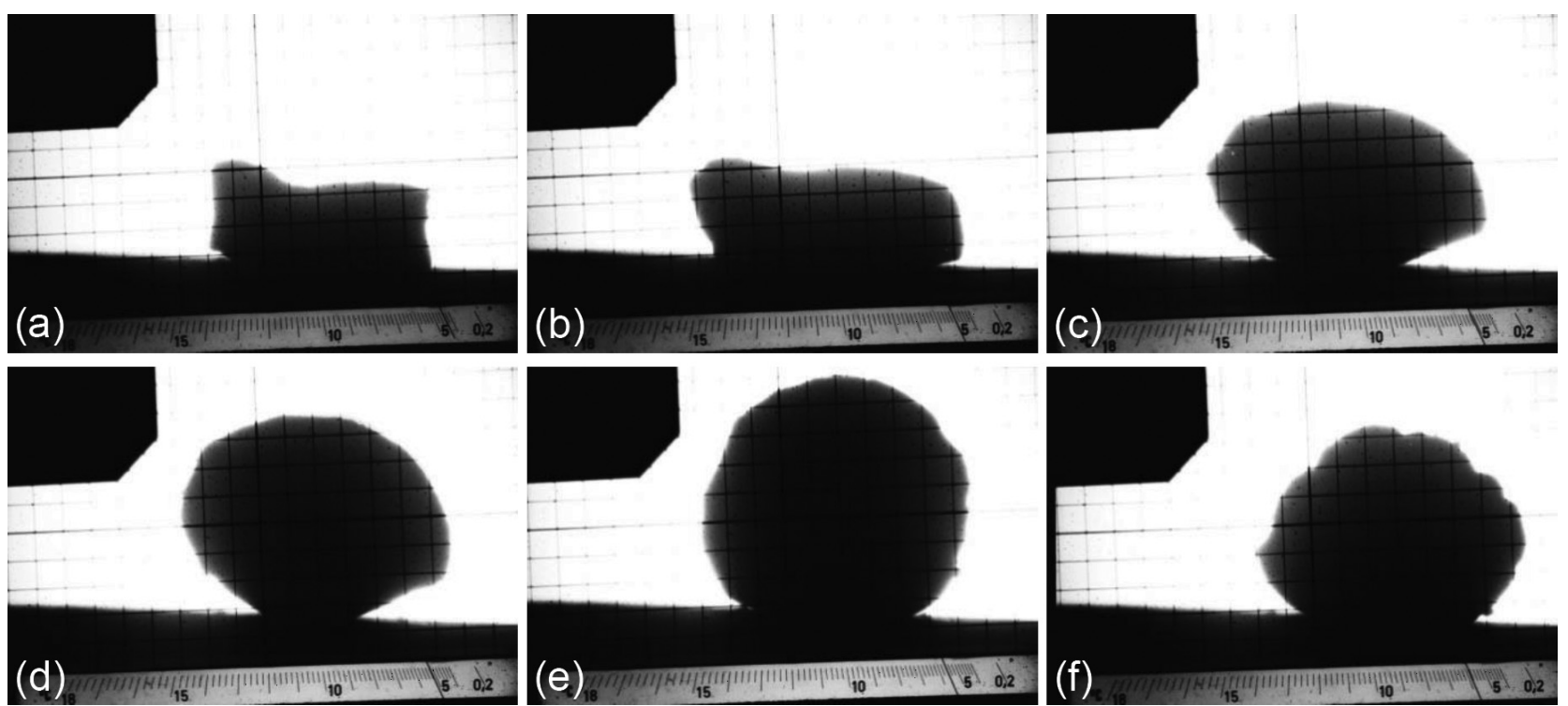

Figure 1: Heating microscope - change of precursor AlSi12 + $\mathrm{TiH}_{2}$ size: a) $420{ }^{\circ} \mathrm{C}$, no changes, b) $500{ }^{\circ} \mathrm{C}$, first noticed change, c) $520{ }^{\circ} \mathrm{C}$, precursor starts rapidly to bloat, d) $525{ }^{\circ} \mathrm{C}$, still rapidly bloating, e) $580{ }^{\circ} \mathrm{C}$, maximum expansion, f) $600{ }^{\circ} \mathrm{C}$, collapse of sample, keeping the shape of a loaf

Slika 1: Segrevalna mikroskopija - sprememba velikosti prekurzorja iz AlSi12 + $\mathrm{TiH}_{2}$ : a) $420{ }^{\circ} \mathrm{C}$, še nobenih sprememb velikosti, b) $500{ }^{\circ} \mathrm{C}$, prve spremembe, c) $520^{\circ} \mathrm{C}$, vzorec začne hitro naraščati, d) $525^{\circ} \mathrm{C}$, vzorec zelo hitro narašča, e) $580{ }^{\circ} \mathrm{C}$, vzorec doseže največjo velikost, f) 600 ${ }^{\circ} \mathrm{C}$, vzorec se sesede, vendar obdrži obliko hlebčka
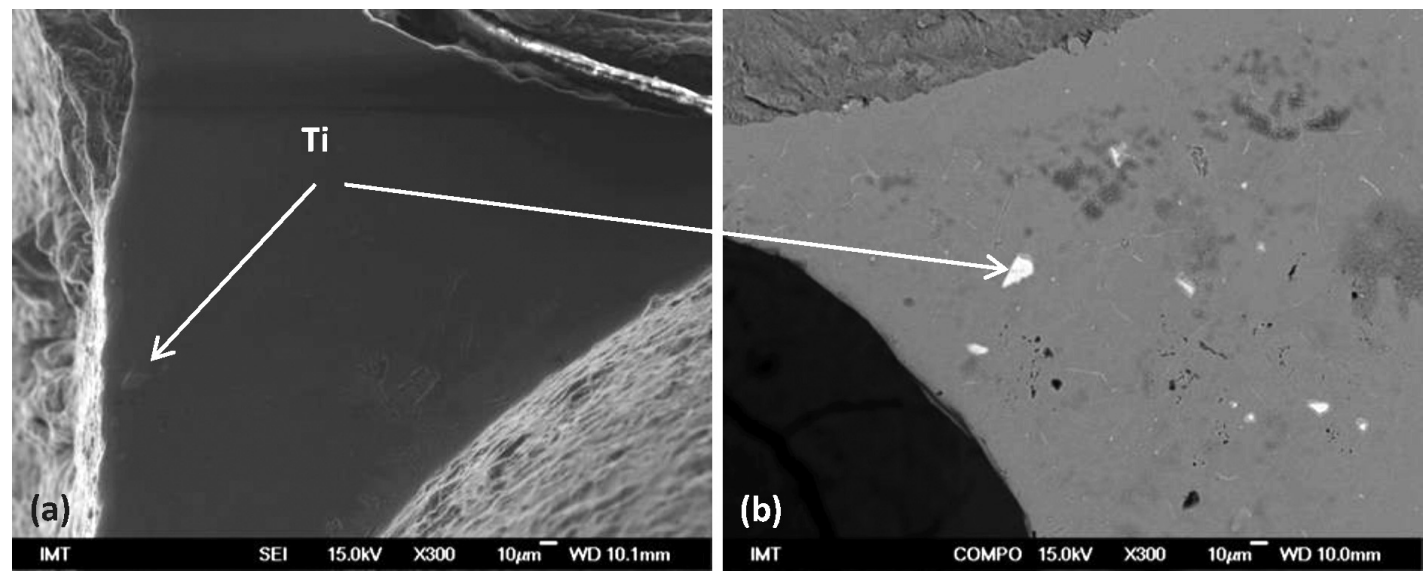

Figure 2: SEM images of thin foam-cell wall with Ti residuals of $\mathrm{TiH}_{2}$ foaming agent: a) SE image and b) BE image

Slika 2: SEM posnetka tanke celične stene aluminijeve pene $\mathrm{z}$ ostanki Ti iz penilnega sredstva $\mathrm{TiH}_{2}$ : a) SE posnetek in b) BE posnetek
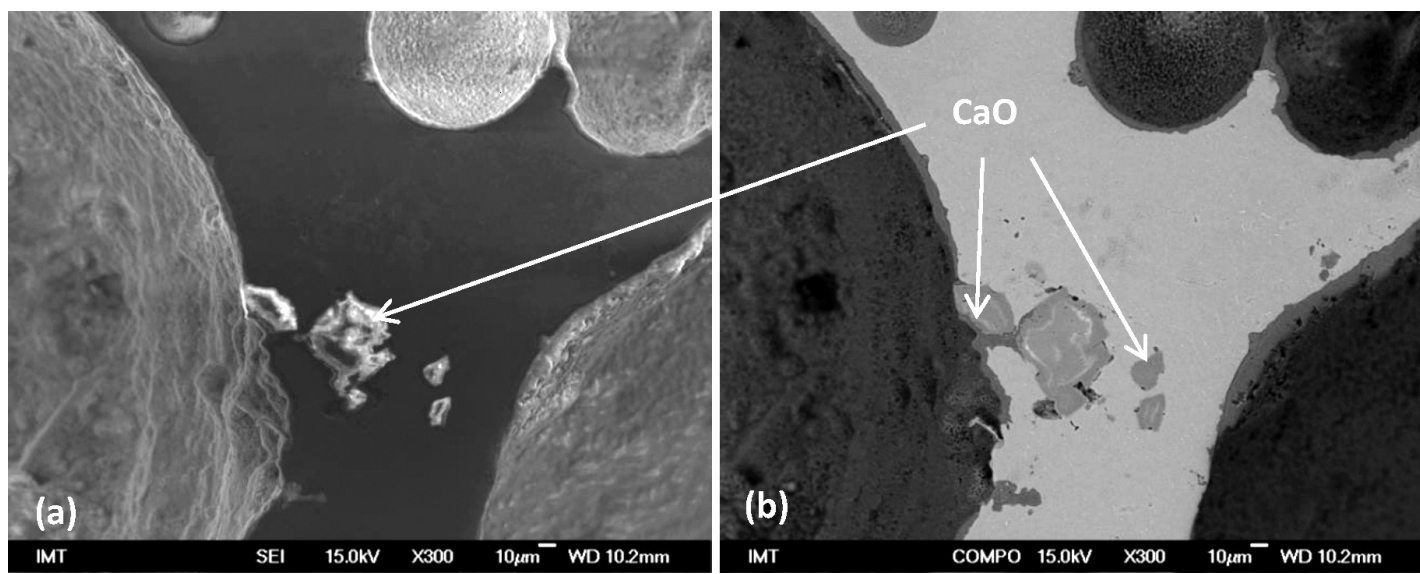

Figure 3: SEM images of thin foam-cell wall with residuals of $\mathrm{CaCO}_{3}$ foaming agent: a) SE image and b) $\mathrm{BE}$ image; the same spot Slika 3: SEM posnetka tanke celične stene z ostanki penila $\mathrm{CaCO}_{3}$ : a) SE posnetek in b) BE posnetek; isto mesto 
ceramic additions to $\mathrm{Al}$ foams during preparation, a special emphasis was given to the positive effects of $\mathrm{CaO}$ particles.

One of the important properties of aluminium foams is also their stability during the foaming process. The quantitative expansion and collapse behavior of the samples were characterized with the mechanical expandometer, in which the precursor was exposed to a constant temperature of $750{ }^{\circ} \mathrm{C}$ for $\mathrm{AlSi} 12+\mathrm{TiH}_{2}$ and 800 ${ }^{\circ} \mathrm{C}$ for $\mathrm{AlSi} 12+\mathrm{CaCO}_{3}$. The expansion was measured with seven samples prepared using $\mathrm{TiH}_{2}$ and $\mathrm{CaCO}_{3}$ agents, respectively, and it was approximately $245 \%$ with the $\mathrm{CaCO}_{3}$ and up to $285 \%$ with the $\mathrm{TiH}_{2}$ precursors. Nevertheless, the $\mathrm{TiH}_{2}$ precursors appeared to collapse faster than the $\mathrm{CaCO}_{3}$ precursors.

Observations in the mechanical expandometer and in the heating microscope revealed that the foams prepared with a foaming agent based on the liberation of $\mathrm{CO}_{2}$ gas were more stable than those that were prepared with the liberation of $\mathrm{H}_{2}$. The obtained results were confirmed by the AES analysis of the interior surfaces of the pores where the oxide layers were analyzed and thus the stability can be explained.6,14,15 Two interior pore surfaces, obtained by foaming AlSi12 $+\mathrm{TiH}_{2}$ and $\mathrm{AlSi} 12+\mathrm{CaCO}_{3}$ mixtures, were analyzed, and the results were compared (Figures 4 and 5). Also, the external surface of the foam was analyzed to see the difference in the interior and exterior surfaces of the foam (Figure 6).

The results showed differences in the thicknesses of the oxide layers on the surface of the pore interior depending on the applied foaming agent and on the surface of the foam exterior. The thickness of the oxide layer on the interior pore surface obtained by foaming with $\mathrm{TiH}_{2}$ was $10-15 \mathrm{~nm}$, while the thickness of the oxide layer on the external surface of the foam was $35-40 \mathrm{~nm}$. On the other hand, the thickness of the oxide layer on the interior pore surface obtained by foaming with $\mathrm{CaCO}_{3}$ was 90-125 nm, while the oxide layer on the external surface of the foam was about $45-60 \mathrm{~nm}$ thick. The difference in

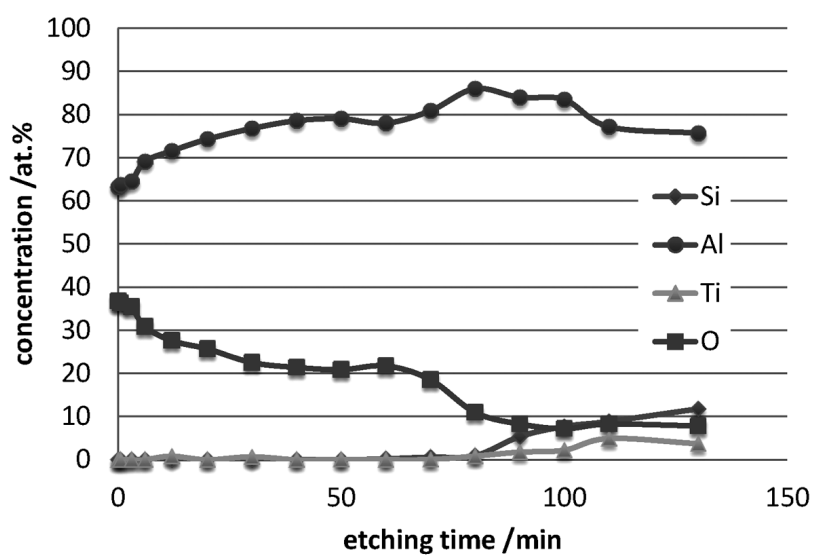

Figure 4: AES depth profiles of the interior surface of the AlSi12 + $\mathrm{TiH}_{2}$ foam pores

Slika 4: Globinski profili AES notranje površine v pori pene AlSi12 + $\mathrm{TiH}_{2}$

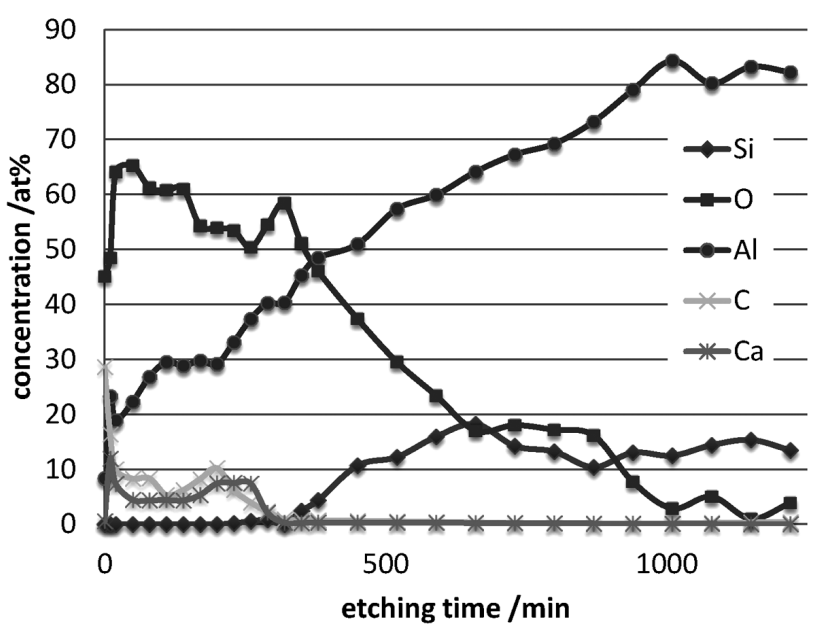

Figure 5: AES depth profiles of the interior surface of the AlSi12 + $\mathrm{CaCO}_{3}$ foam pores

Slika 5: Globinski profili AES notranje površine v pori pene AlSi12 + $\mathrm{CaCO}_{3}$

the oxide layer thicknesses was explained by the fact that $\mathrm{H}_{2}$ represented a reduction atmosphere in the material, and oxygen formed on the surface of the matrix material only a thin oxide layer. Oxide was present in the material as a thin oxide layer on the surface of the powder particles. On the other hand, the $\mathrm{CaCO}_{3}$ powder created a $\mathrm{CO}_{2}$ atmosphere during the foaming process, so that the oxide layer on the pore surface was easily formed. Thick oxide layers enabled better stability of the foams produced by foaming agents based on $\mathrm{CO}_{2}$. However, in both cases there was no great difference in the thicknesses of the oxide layers on the external surface.

The question appears, why $\mathrm{CO}_{2}$-based foaming agents are not yet more widely used? And the answer is that agents releasing $\mathrm{CO}_{2}$ need higher temperatures for the liberation of the gas and the needed temperature is approximately $100{ }^{\circ} \mathrm{C}$ above the melting point of pure aluminium ${ }^{10}$. In such a case, the matrix material is already molten and the viscosity of such material is not high enough to prevent gas escaping out of the material.

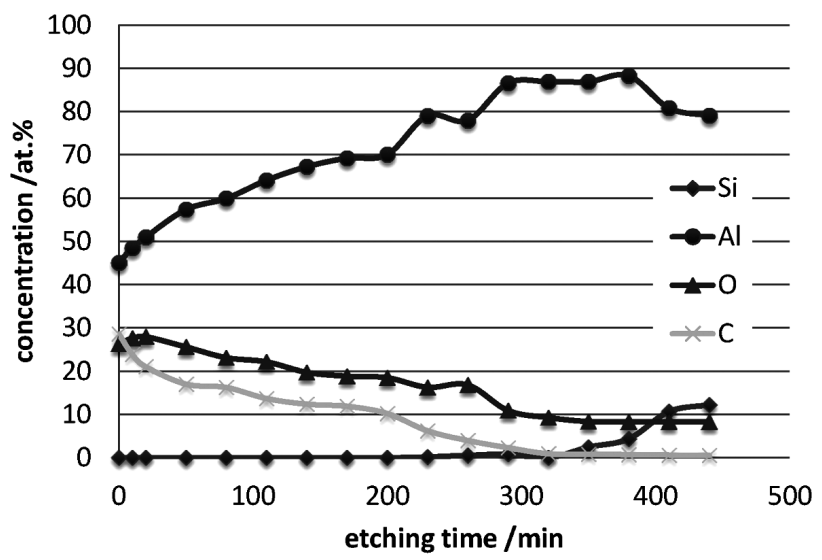

Figure 6: AES depth profiles of the exterior $\mathrm{AlSi12}+\mathrm{TiH}_{2}$ foam surface

Slika 6: Globinski profili AES zunanje površine pene $\mathrm{AlSi} 12+\mathrm{TiH}_{2}$ 

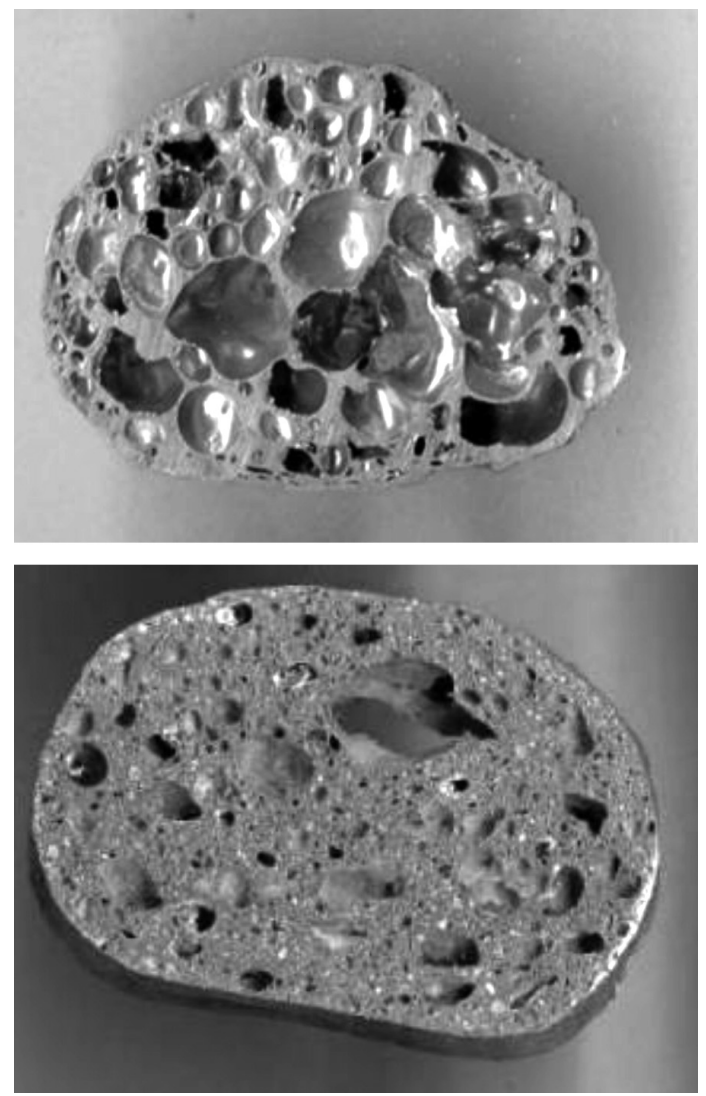

Figure 7: Images of $\mathrm{Al}$ foam, cut from loaf: a) $\mathrm{AlSi} 12+\mathrm{TiH}_{2}$ and b) $\mathrm{AlSi} 12+\mathrm{CaCO}_{3}$

Slika 7: Posnetka Al pene, odrezan Al hlebček: a) AlSi12 + $\mathrm{TiH}_{2}$ in b) $\mathrm{AlSi} 12+\mathrm{CaCO}_{3}$

The solution is to pre-heat the precursors for some time before the foaming process begins. When foaming agents in those precursors are then exposed to an elevated temperature, decomposition has already started and the agent did not need such a long time to decompose completely, while the matrix aluminium has insufficient time to melt completely.

The sizes and shapes of the pores in the foams prepared by exposure to $\mathrm{H}_{2}$ or $\mathrm{CO}_{2}$ gas are different. $\mathrm{H}_{2}$ gas forms spherical pores, while $\mathrm{CO}_{2}$ forms smaller pores of not completely spherical shape; they are slightly elongated in the horizontal direction (Figure 7). However, the stability of foams is better when a $\mathrm{CO}_{2}$-based foaming agent is used, but the pore shapes and consequently the mechanical properties in the vertical direction are better when using $\mathrm{H}_{2}$-based foaming agents. The final application of the foamed material determines the selection of the foaming agent as well as the selection of the matrix material. On the other hand, the use of a combination of both foaming agents in a well-defined proportion can be an alternative.

\section{CONCLUSIONS}

$\mathrm{CaCO}_{3}$ is a good substitute for the expensive and more widely used $\mathrm{TiH}_{2}$ foaming agent, though some properties of foams, like the stabilization of pores, are in this case even better. Natural oxidation of the pore surfaces inside the material, as well as the oxidation of external surfaces, helps to stabilize foams so that they do not collapse after the completed foaming.

The oxide layers detected by the AES analysis on the surface of aluminium powders helped to prevent premature melting of the matrix material and enabled foaming agents to decompose before the matrix material melted and lost sufficient viscosity. Similar case is observed when using $\mathrm{TiH}_{2}$ foaming agent that decomposes at a relatively low temperature, but the additional oxide layer on the surface of the powder delays the beginning of the decomposition as it was pre-studied and confirmed in the literature.

According to ${ }^{12,13}$ and from our research the conclusion can be made that a thicker oxide layer and the residuals of the ceramic solid particles from the $\mathrm{CaCO}_{3}$ foaming agent give an opportunity to foaming agents based on $\mathrm{CO}_{2}$ to be used more often in the production of aluminium foams.

Nevertheless, the stability of the foams is better when a $\mathrm{CO}_{2}$-based foaming agent is used, but the pore shapes are more spherical and consequently the mechanical properties, as known from the literature, are higher when $\mathrm{H}_{2}$-based foaming agents are used, so the use of a combination of both foaming agents in a well-defined proportion can be an alternative.

\section{Acknowledgements}

This work was supported by the "Physics and chemistry of porous aluminum for Al panels capable of highly efficiently energy absorption" project L2-2410 (D), funded by the Slovenian Research Agency.

\section{REFERENCES}

${ }^{1}$ A. H. Benouali, L. Froyen, J. F. Delerue, M. Wevers, Mechanical analysis and microstructural characterisation of metal foams, Materials Science and Technology, 18 (2002) 5, 489-494, doi:10.1179/026708302225002056

${ }^{2}$ M. Nosko, F. Simancik, R. Florek, Reproducibility of aluminum foam properties: Effect of precursor distribution on the structural anisotropy and the collapse stress and its dispersion, Materials Science and Engineering A, 527 (2010) 21-22, 5900-5908,

doi:10.1016/j.msea.2010.05.073

${ }^{3}$ M. Haesche, J. Weise, F. Garcia-Moreno, J. Banhart, Influence of particle additions on the foaming behaviour of AlSi11/TiH2 composites made by semi-solid processing, Materials Science and Engineering A, 480 (2008) 1-2, 283-288, doi:10.1016/j.msea.2007.07. 040

${ }^{4} \mathrm{~J}$. Banhart, Manufacture, characterisation and application of cellular metals and metal foams, Progress in Materials Science, 46 (2001) 6, 559-632, doi:10.1016/S0079-6425(00)00002-5 


\section{PAULIN: STABILITY OF CLOSE-CELL Al FOAMS DEPENDING ON THE USAGE OF DIFFERENT FOAMING AGENTS}

${ }^{5}$ I. Duarte, J. Banhart, A study of aluminium foam formation - Kinetics and microstructure, Acta Materialia, 48 (2000) 9, 2349-2362, doi:10.1016/S1359-6454(00)00020-3

${ }^{6}$ I. Paulin, B. Šuštaršič, V. Kevorkijan, S. Škapin, M. Jenko, Synthesis of aluminium foams by powder-metallurgy process: compacting of precursors, Mater. Tehnol., 45 (2011) 1, 13-19

${ }^{7}$ I. Duarte, P. Weigand, J. Banhart, Foaming kinetics of aluminium alloys, In: J. Banhart, N. A. Ashby, N. A. Fleck (Eds.), Metal Foams and Porous Metal Structures, MIT Verlag, Bremen, Germany 1999, 97-104

${ }^{8}$ I. Jeon, T. Asahina, K. J. Kang, S. Im, T. J. Lu, Finite element simulation of the plastic collapse of closed-cell aluminum foams with X-ray computed tomography, Mechanics of Materials, 42 (2010) 3, 227-236, doi:10.1016/j.mechmat.2010.01.003

${ }^{9}$ A. E. Markaki, T. W. Clyne, The effect of cell wall microstructure on the deformation and fracture of aluminium-based foams, Acta Materialia, 49 (2001) 9, 1677-1686
${ }^{10}$ I. Paulin, Synthesis and characterization of Al foams produced by powder metallurgy route using dolomite and titanium hydride as a foaming agents, Mater. Tehnol., 48 (2014) 6, 943-947

${ }^{11} \mathrm{P}$. Weigand, Untersuchung der Einflussfaktoren auf die pulvermetallurgische Herstellung von Aluminiumschäumen, Dissertation, RWTH Aachen University, Aachen 1999

${ }^{12}$ J. Baumeister, J. Weise, A. Jeswein, M. Busse, M. Haesche, Metalic foam production from $\mathrm{AlMg} 4.5 \mathrm{Mn}$ recycling machining chips by means of thixocasting and the effects of diferent additions for stabilization, MetFoam 2007, Montreal, Canada 2007

${ }^{13}$ A. R. Kennedy, S. Asavavisitchai, Effect of ceramic particle additions on foam expansion and stability in compacted $\mathrm{Al}-\mathrm{TiH}_{2}$ powder precursors, Adv. Eng. Mater., 6 (2004) 6, 400-402, doi:10.1002/adem.200405145

${ }^{14}$ J. Banhart, Metal foams: Production and stability, Adv. Eng. Mater., 9 (2006) 8, 781-794, doi:10.1002/adem.200600071

${ }^{15}$ A. Haibel, A. Rack, J. Banhart, Why are metal foams stable?, Applied Physics Letters, 89 (2006), 154102, doi:10.1063/1.2357931 